ISSN 1997-5902

\title{
Composition of arbuscular mycorrhizal fungi associated with cassava (Manihot esculenta Crantz) cultivars as influenced by chemical fertilization and tillage in Cameroon
}

\author{
Didier Aime Boyogueno BEGOUDE², Papa Saliou SARR ${ }^{1^{*}}$, Tatiana Laure Yondi MPON ${ }^{3}$, Didier Alexis \\ OWONA², Miraine Ndacnou KAPEUA², Shigeru ARAKI ${ }^{1}$ \\ ${ }^{1}$ Centre for African Area Studies, Graduate School of Asian and African Area Studies, Kyoto University, 46 \\ Shimoadachi-cho, Yoshida, Sakyo-ku, Kyoto 606-8501, Japan \\ ${ }^{2}$ Regional Biocontrol and Applied Microbiology Laboratory, Institute of Agricultural Research for Development \\ (IRAD), P.B. 2067, Yaoundé, Cameroon \\ ${ }^{3}$ Department of Crop Production, Faculty of Agronomy and Agricultural Science, University of Dschang, P.O. Box \\ 221 Dschang, Cameroon \\ *Email of corresponding author: pesseus77@yahoo.fr
}

Original submitted in on $18^{\text {th }}$ December 2015. Published online at www.m.elewa.org on $29^{\text {th }}$ February 2016 http://dx.doi.org/10.4314/jab.v98i1.4

\begin{abstract}
Objectives: Arbuscular mycorrhizal fungi (AMF) form root symbiotic relationships with higher plants, but their abundance and symbiotic effectiveness may be influenced by agricultural practices. This study investigated the effect of $\mathrm{N}-\mathrm{K}$ fertilization and tillage on soil's AMF composition and root colonization of some selected cassava varieties in Eastern and Southern Cameroon.

Methodology and results: Three cassava varieties were grown in Eastern Cameroon in tilled and non-tilled plots. In Southern Cameroon, five varieties were grown in non-tilled plots, with half of them receiving NPK (10-10-20) fertilization. Collected soil and root samples were analyzed to quantify and describe the AMF communities. AMF root colonization was 35\% regardless to the variety and farming system in Eastern region, while it reached $45 \%$ in Southern Cameroon. Root colonization varied among varieties within and between locations. Fertilized plots displayed lesser microbial density than non-fertilized plots and the tillage highly reduced the root colonization as well as the density of spores.

Conclusions and application of findings: In Eastern and Southern parts of Cameroon, the identified AMF communities in a symbiotic relationship with cassava were ascribed to the three genera Glomus, Gigaspora and Acaulospora. Among these three genera, Glomus was predominant in all the sites; indicating its wide geographical distribution in Cameroon and affinity with cassava. Species of the genus Glomus may therefore be used during mycorrhizal inoculations of cassava. However, AMF root colonization varies in relation to the variety type and the environment; with the southern region of Cameroon showing the higher colonization levels. This study revealed that to obtain higher AMF spores densities in soil and maximize root colonization, cultivation systems with a lesser soil disturbance and fertilization is recommendable in cassava cultivation.
\end{abstract}

Key words: Arbuscular mycorrhiza funji (AMF), Cameroon, Cassava cultivation, Chemical fertilization, Tillage 


\section{Begoude et al. J. Appl. Biosci. 2016 Composition of arbuscular mycorrhizal fungi associated with}

cassava (Manihot esculenta Crantz) cultivars as influenced by chemical fertilization and tillage in Cameroon

\section{INTRODUCTION}

The symbiotic association between arbuscular mycorrhizal fungi (AMF) and the roots of plants is widespread in the natural environment. AMF establish symbiosis with approximately $80 \%$ of the vascular plant species in all terrestrial biomes (Smith et al., 2010). There are of great ecological importance, because arbuscular mycorrhizae are involved in the most widespread form of plant symbiosis and often improve plant productivity (Fedderman et al., 2010). In all ecosystems, rhizosphere organisms act in support of plant growth and productivity in several ways. AMF are one such soil organisms which play a crucial role in linking plants and soil, transporting mineral elements such as immobile phosphate ions (Miransari et al., 2009), micronutrients, including N, $\mathrm{K}$, and $\mathrm{Mg}$ (Veresoglou et al., 2010), as well as micronutrients (Kim et al., 2009) to plants. AMF are also known to increase resistance to soil pathogens (Lingua et al., 2002), increase tolerance to salinity, heavy metals and drought stress (Li et al., 2011). Therefore, they are important in tropical food crop based sustainable agriculture. Cassava (Manihot esculenta Crantz) is one of the main staple crops in Cameroon and is cultivated in all the country's agroecosystems. Its tubers and leaves constitute primary sources of food for nearly 10 million of Cameroonian with a concentration in 8 regions out of 10 (Tolly, 2013). Cassava grows easily even under drastic agronomic conditions and its production systems are mostly small-scale and subsistence oriented. Because of low use of the external inputs (fertilizers), soil fertility depletion associated with the action of emergent diseases gradually reduces the productivity. Therefore, nourishing the Cameroonian population remains a challenge, which requires a sustainable increase in agricultural productivity. Among the strategies under implementation, the government of Cameroon is recently promoting actively the adoption of disease-resistant improved cassava varieties. In many parts of the country, soil fertility management through the application of animal manure, by the mulching or incorporation of crop residues of intercrops or the use of green manures through leguminous cover crops as well as chemical fertilizers in a lower extend, and soil tillage are among other methods that help to increase and sustain cassava production in Cameroon. Cassava production is often blamed for degrading the soil, and many long-term trials with cassava have shown that yield will decline when the crop is grown for many years in the same fields. However, this is true for many other crops as well, due to the removal of nutrients in the harvested products. Nonetheless, many long-term fertilizer trials have shown that this is not necessarily the case if cassava is fertilized with the right amount and balanced of nutrients. Understanding how these agricultural practices used in cassava cultivation affect AM colonization and abundance in soil is therefore an important issue.

Cassava is a highly mycotrophic plant (Oyetunji \& Osonubi, 2007), with mycorrhizal associations revealed to improve the plant's biomass production (Ceballos et al., 2013). However, the efficiency of the association could vary with the cultivar (Declerck et al., 1995), the AM fungal species/strain (Yano- Melo et al., 1999), and the agricultural management practices (Adriano-Anaya et al., 2006). Douds \& Millner (1999) indicated that some agricultural practices used in farming systems, e.g., fertilization or frequent soil disturbance through tillage, may affect indigenous AMF communities. In several studies, AMF communities were found to have deteriorated in species composition in intensively managed agricultural systems compared with low-input systems (Sieverding, 1989; Galvez et al., 2001). Other studies, however, show only small or no differences between contrasting systems (FrankeSnyder et al., 2001; Vestberg et al., 2009). Although it can be seen that AMF play an important role in many ecosystems, a number of studies documenting the influence of management practices on AMF abundance have been done in majority in temperate ecosystems and relatively little is known about the effects of land use changes on AMF abundance in the tropical soils. A better understanding of the influence of land use changes on AMF abundance will help in improving their management, thus leading to improve plant 
productivity in the poor soils. Determining the effects of land use changes on the abundance of AMF in the tropical soils will also be useful in designing more sustainable management practices. In this paper, results from two experiments conducted in collaboration with farmers in southern and eastern Cameroon have

\section{MATERIALS AND METHODS}

Studies sites: The study was carried out at Andom and Bityili villages, respectively (Figure 1). Andom village $\left(5^{\circ} 15^{\prime} \mathrm{N}, 13^{\circ} 30^{\prime} \mathrm{E}\right)$ belongs to the Lom and Djerem division, eastern region of Cameroon. This area is characterized by a tropical climatic; 7 months of rainy season extending from April - October, including short dry spells from July - August, and a 5-month dry season from November - March. The average rainfall is $1500 \mathrm{~mm}$ (Araki \& Saito, 2013), and Andom village is located at an altitude of $650 \mathrm{~m}$ asl. The average temperature in the region is $25^{\circ} \mathrm{C}$. Andom is located at the forest-savannah transition zone, with the savannah forming the majority of the land. Bityili village $\left(2^{\circ} 56^{\prime} \mathrm{N}\right.$, $11^{\circ} 11^{\prime}$ E) belongs to the Mvila division, South Region been reported. The first experiment aimed at determining the effect of chemical fertilization as well as cassava varieties on AMF abundance and density, whereas the second experiment aimed at determining the effect of tillage on AMF abundance.

of Cameroon. This area is situated few kilometres north of the Ebolowa town. The rainfall $(1600-2000 \mathrm{~mm})$ is bimodal (march-June and September-November). Bityili village is located at an altitude of $584 \mathrm{~m}$ asl. The annual average temperature is about $24^{\circ} \mathrm{C}$; the area is in the midst of the forest environment, undulating with incise drivers and some widely distributed swampy-drainage ways. In both areas, the livelihood for most villagers comes from agriculture and hunting. The primary crop cultivated is cassava, and cassava stiff porridge is the villagers' staple food. Our preliminary field survey revealed that more than 10 local cassava varieties are cultivated in each of these two study sites.

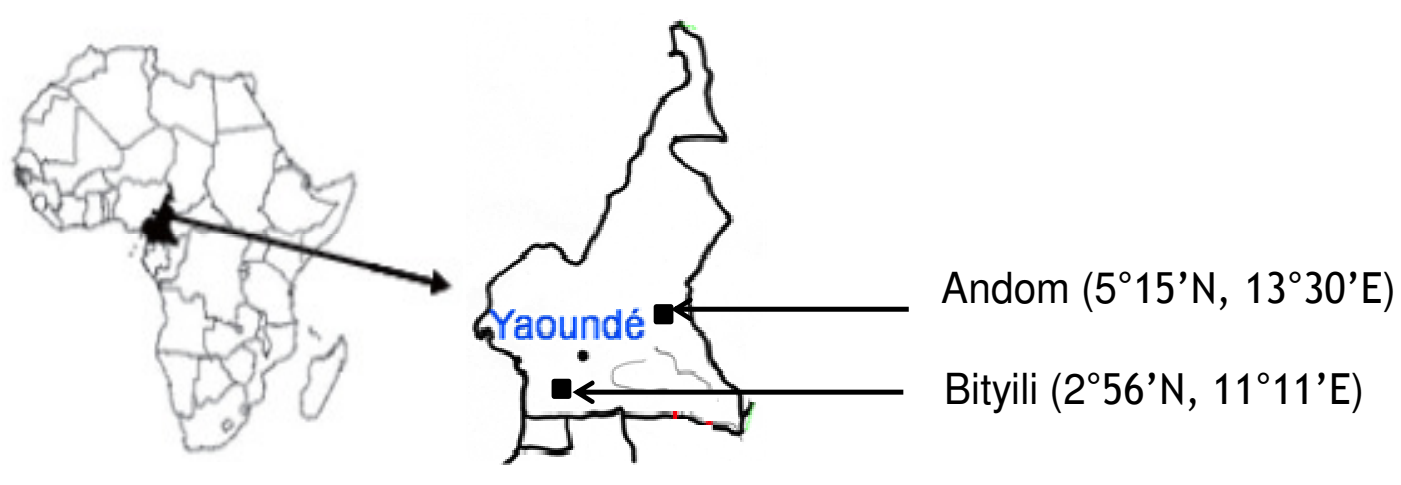

Figure 1: Localization of the experimental sites in Cameroon

Effect of fertilization and variety type on AMF abundance and density composition (Bityili, Southern Cameroon): Three sites were identified namely Mekoto, Minkon Mongon and Tyele. Minkon Mingon was a fallow land for over 10 years, whereas Mekoto and Tyele were cultivated with cassava 4 years before the establishment of trial on July 2012. The three sites were later cultivated with cassava for one season (July 2012 to July 2013) and for a second season from September 2013 to September 2014. Described in this study were collected from the second season cultivation. In each site, five varieties; two IITA (International Institute of Tropical Agriculture) improved cassava varieties (TMS-96/1414 and TMS-92/0326), one IRAD (Institute of Agricultural Research for Development) improved variety (8034) and two local accessions selected by farmers (Ekobele and Ngon kribi) were selected for use in the experiment. Those varieties differed in their morphological characteristics including growth habit of stem, stem colour, outer and inner root skin colour, leaf colour, root fresh colour, pubescence of young leaf. Cassava cuttings of $25 \mathrm{~cm}$ 


\section{Begoude et al. J. Appl. Biosci. 2016 Composition of arbuscular mycorrhizal fungi associated with cassava (Manihot esculenta Crantz) cultivars as influenced by chemical fertilization and tillage in Cameroon}

length from each variety were prepared and planting was done following contour lines at the spacing of $1 \mathrm{~m}$ $x 1 \mathrm{~m}$ on flat soil. The five varieties were replicated six times in each site, in a complete randomized block design giving 30 plots per site. The size of each plot was $150 \mathrm{~m}^{2}(15 \mathrm{~m} \times 10 \mathrm{~m})$ with $2 \mathrm{~m}$ spacing between plots. Planting was done respectively at Tyele, then Minkon Mingon and lastly at Mekoto. Of the six replicates per variety in a site, three were fertilized using NPK at 40-50 N, 40-60 $\mathrm{P}_{2} \mathrm{O}_{5}$ and 80-120 K2O/ha (10N-10P-20K). The chemical fertilizers were top dressed twice during the growing cycle at three and seven months after planting when the soil was humid in order to reduce the volatilization. Manual weeding was carried out three times during the growth cycle (12 months) when the weed incidence was getting high.

Effect of tillage and variety type on AMF abundance and density (Andom, Eastern Cameroon): Three sites (I, II, III) $2 \mathrm{~km}$ apart, were selected as the experimental fields. They were established in coordination with farmers and village leaders in natural bush fallows where no previous crops had been grown for over 7 years. Trial crops were planted on three different inclines (flat, gentle and relatively steep slope); site II was flatter than site I and III. Furthermore, the three sites contained slightly different vegetation. The vegetation at site I comprised mainly Chromolaena odorata (L) R.M.King \& H.E. Robinson, site II was dominated by Imperata cylindrica (L)P. Beauv., and site III, located in the savannah zone and traditionally used for livestock grazing, was a mosaic of $I$. cylindrica (lower density compared to site II), C. odorata, and a few trees. Two varieties of cassava used in the first experiment namely TMS-92/0326 and TMS-96/1414 were involved in the experiment. These varieties were developed through conventional breeding by IITA and partners. The varieties were characterized by improved nutritional qualities and richness in carotenoids, iron and zinc. They were selected following farms trials and based on desirable traits, including a high root yield, yield stability, food quality, plant architecture and resistance to pests and diseases. TMS-96/1414 has a branching structure with medium-size green leaves and is shorter than TMS-92/0326, which also has bigger green leaves. Both varieties produce white tubers at maturity. Part of the soil in each site was tilled with a power tiller at planting period. The treatments in this study consisted of tilled TMS-92/0326 and non-tilled TMS-92/0326, tilled TMS-96/1414 and non-tilled TMS$96 / 1414$ with two replications per site in a complete randomized design. Site I plot was $15 \mathrm{~m}$ x 8 m (120 $\left.\mathrm{m}^{2}\right)$, site II was $20 \mathrm{~m} \times 7 \mathrm{~m}\left(140 \mathrm{~m}^{2}\right)$, and site III was 15 $\mathrm{m} \times 8.5 \mathrm{~m}\left(127.5 \mathrm{~m}^{2}\right)$. The trial was carried out in the 2013-2014 cropping season, $20 \mathrm{~cm}$ long cassava sticks with at least 5-7 buds were planted late September 2013 at a distance of $1 \mathrm{~m} \times 1 \mathrm{~m}$ apart, giving a planting density of $1 \mathrm{plant} / \mathrm{m}^{2}$. No fertilizer was used, the experiment was carried out under natural conditions and the fields were maintained free from weeds.

Sampling and data collection: roots and soil: Sampling was done 10 months after planting in both trials during the short dry season. Data were collected soil $\mathrm{pH}$, nutrients $(\mathrm{N}, \mathrm{C}, \mathrm{Ca}, \mathrm{Mg}$ and $\mathrm{P})$ and $\mathrm{CEC}$, on root colonization (i.e. frequency) by the $A M$ fungi, spores densities and distribution. Three plants (replicates) per variety chosen from the three replicated plots were sampled. For each plant, a sub-sample of fine roots was collected and these three sub-samples were mixed up to make one composite root sample per variety and per treatment and stored in 50\% ethanol until required. Soil sub-samples were taken at 0-15 cm depth around the stem in the tuber/root region of each plant sampled. These sub-samples were mixed up to form one composite sample per treatment. The samples were then transported to the laboratory and air-dried. A $300 \mathrm{~g}$ dried soil sample from each composite soil was used for direct spore extraction, 300 $\mathrm{g}$ were used as inoculum for AMF trapping and $300 \mathrm{~g}$ were kept for soil chemical analysis.

Soil analysis: The samples were air-dried and ground to pass through a $2 \mathrm{~mm}$ sieve. Soil $\mathrm{pH}$ was determined in a 1:2.5 (w/v) soil: water suspension. Organic carbon was determined by chromic acid digestion (Black, 1982) and spectrophotometric analysis (Heanes, 1984). Soil N (\%) was determined by wet acid digest (Buondonno et al., 1995) and analyzed colorimetrically (Anderson \& Ingram, 1993). Exchangeable Ca, Mg, K, and $\mathrm{Na}(\mathrm{cmol}(+) / \mathrm{kg})$ were extracted using $1 \mathrm{M}$ ammonium acetate and determined by atomic absorption spectrophotometry. Soil cationic exchange capacity (CEC) was calculated from organic carbon (\%) using the regression equation $(\mathrm{CEC}=3.024 \times$ Org. $\mathrm{C}+$ 2.05) proposed by Araki \& Sarr (2013) for oxisol of eastern Cameroon. Soil available phosphorus (ppm) was extracted by the Bray-1 procedure (Bray \& Kurtz, 1945) and analyzed using the molybdate blue procedure described by Murphy \& Riley (1962).

Assessment of cassava AMF on root colonization: The modified method of Philips and Hayman (1970) was used to stain roots. One to two-cm segments of root samples were placed in $5 \% \mathrm{KOH}$ solution for $24 \mathrm{~h}$ at room temperature and rinsed three times in water on 
a fine sieve. The root samples were acidified in $10 \%$ $\mathrm{HCl}(\mathrm{v} / \mathrm{v})$ for $15 \mathrm{~min}$ and then stained with $0.01 \%(\mathrm{w} / \mathrm{v})$ acid fushin for $24 \mathrm{~h}$ at room temperature. Root segments of each species were selected randomly from the stained samples. Three replicates of 10 roots per slide were assessed for the presence or absence of AMF structures (arbuscules, vesicles and hyphae) using a stereomicroscope. Mycorrhizal frequency ( $\mathrm{F} \%)$ was given as the ratio between colonized root fragments and the total number of root fragments observed.

Trapping and culturing of AMF: Trap pot cultures were established using soils directly sampled from cassava fields. One hundred $g$ of field soils were diluted with sterilized river sand (1:1) in one litre pot. Vigna unguiculata (L.) Walp. or Sorghum bicolor (L.) Moench seeds were surface sterilized with sodium hypochlorite $(10 \% \mathrm{v} / \mathrm{v})$ for $10 \mathrm{~min}$ and thoroughly rinsed with sterilized water. The seeds were separately pregerminated in dark for three days in plastic buckets sterilized with sodium hypochlorite and alcohol and having hydrophilic cotton layers at the bottom. After germination, seedlings were selected for uniform size and then transplanted into pots (two seedlings per plant species per pot). These pots were placed in a greenhouse and grown for 70 days during which tap water was applied every two days in average. During trapping, the pots were fertilized every 15 days with a nutritive solution (CODAFOL 14-6-5) applied at 25 $\mathrm{ml} / 10$ I of water when plants started showing signs of deficiencies.

\section{RESULTS}

Soil characteristics of the study sites: The soils from the two study sites used for spore counts and trapping (collected under cassava plants) together with noncultivated controls were chemically analyzed for macro and micronutrients levels and results are reported in Table 1. Under non-cassava cultivation (control), Bityili soils showed significantly lower CEC but significantly, higher available P compared to Andom soils. Soil data collected from cassava-cultivated plots showed significantly higher available $\mathrm{P}$ (increased in value compared to its control), sum of exchangeable cations $(\mathrm{S})$ and total nitrogen $(\mathrm{N})$ but significantly lower $\mathrm{C} / \mathrm{N}$ as compared to that of Andom. Not all other soil physicochemical characteristics were significantly different in both sites for either control or cultivated systems.
AMF spore extraction from soil: AMF spores were extracted from soil by wet sieving and decanting (Gerdemann \& Nicolson, 1963) followed by centrifuging in water and in a $50 \%$ sucrose solution (Walker et al., 1982). A $710 \mu \mathrm{m}, 250 \mu \mathrm{m}, 125 \mu \mathrm{m}$ and $45-\mu \mathrm{m}$ sieve were used for wet sieving. After centrifuging, the spores were transferred to a dish of water for examination under a dissecting microscope at magnifications up to 50 times with illumination by incident light from a fibreoptic, quartz-halogen light source. The grid intersect method (Giovanetti \& Mosse, 1980) was used to determine the spore number, defined as total number of spores found in $100 \mathrm{~g}$ dry weight of soil. Spores were characterized and, whenever possible, identified at the genus level from diagnostic slides made of the spores and associated structures (e.g. hyphae, auxillary cells) viewed at $\times 100$ under a high-power microscope (www .bio.ukc.ac.uk/beg/protocols/extraction.htlm) supported by current identification manuals (International Culture Collection of Vesicular and Arbuscular Endomycorhizal fungi http://invam.caf.wvu.edu/Myc_Info/Taxonomy/ species.htlm]).

Statistical analysis : All data were subjected to analysis of variance (ANOVA) using the CropStat 7.2 software (International Rice Research Institute, Manila, Philippines) at a probability level of $5 \%$. Mean separation was performed using Fisher's least significant difference (LSD) test whenever a significant result $(P<0.05)$ was obtained. At each location (Bityili or Andom), a separated on-way ANOVA was applied to data of each site.

Compared to the Andom soil, the Bityili soil was higher in total $\mathrm{P}$ by a factor of 2 when both soils are cultivated. Soil pH was similar in bith sites but without cultivation, Bityili soil was more acidic ( $\mathrm{pH} 4.74$ ) compared to Andom soil (pH 5.17).

Effect of fertilization and cassava varieties on AMF abundance and density: The microscopic analysis of the mycorhizal colonization of cassava in the study area revealed that this plant is a good host for AMF. All the plants sampled were colonized by the AM of which all or a part were recognisable by the typical morphological structures that are the hyphae, the arbuscules, the vesicles and the intracellular spores (Figure 2). 


Begoude et al. J. Appl. Biosci. $2016 \quad$ Composition of arbuscular mycorrhizal fungi associated with
cassava (Manihot esculenta Crantz) cultivars as influenced by chemical fertilization and tillage in Cameroon

Table 1: soil characteristics of the fields

\begin{tabular}{|c|c|c|c|c|c|c|c|c|}
\hline \multirow[b]{2}{*}{ System/location } & $\mathrm{OM}$ & C & $\mathbf{N}$ & \multirow{2}{*}{$\mathrm{C} / \mathrm{N}$} & $\mathbf{S}$ & CEC & \multirow[b]{2}{*}{$\mathrm{pl}$} & \multirow{2}{*}{$\begin{array}{l}\text { BrayP } \\
\mathrm{mg} \mathrm{kg}^{-1}\end{array}$} \\
\hline & \multicolumn{3}{|c|}{$\mathrm{g} \mathrm{kg}^{-1}$} & & \multicolumn{2}{|c|}{$\mathrm{cmol} \mathrm{kg}^{-1}$} & & \\
\hline Control Bityili & 46.37 & 26.90 & 3.01 & 08.94 & 4.85 & $08.02 \mathrm{a}$ & 4.74 & $6.47 \mathrm{~b}$ \\
\hline Control Andom & 53.15 & 30.83 & 2.34 & 13.17 & 4.93 & $10.47 b$ & 5.27 & $4.76 a$ \\
\hline Sign. Trait (P0.05) & ns & ns & ns & ns & ns & * & ns & * \\
\hline Cultivated Bityili & 56.96 & 34.00 & $4.16 \mathrm{~b}$ & $08.17 \mathrm{a}$ & $7.26 \mathrm{~b}$ & 11.17 & 5.51 & $11.31 \mathrm{~b}$ \\
\hline Cultivated Andom & 57.61 & 33.42 & $2.68 \mathrm{a}$ & $12.47 b$ & $5.18 \mathrm{a}$ & 11.48 & 5.18 & $04.57 \mathrm{a}$ \\
\hline Sign. Trait (P0.05) & ns & ns & *** & *** & *** & ns & ns & * \\
\hline
\end{tabular}

In a column of controls or cultivated systems, values with different letters $(a, b)$ are significantly different at the indicated level of significance. ${ }^{* * *}$ Significant at $P \leq 0.001$, * significant at $P \leq 0.05$. In each system (control or cultivated), one-way ANOVA was applied using CropStat ver.7.2. S: sum of exchangeable cations, OM: organic matter.

Overall, AMF abundance as represented by the colonization frequency was similar $(45 \%)$ for all the sites. In each site, the frequency of root colonization was compared for the full set of varieties and fertilization. The effect of cassava variety on the frequency of root colonization was significant $(P<0.05)$ in the sites of Mekoto, Mingon Migon and Tyele (Table 2). At Mekoto, significantly higher value of root colonization frequency was observed in Ekobele and Ngon Kribi with both $53.34 \%$ in average (regardless to the fertilization) as compared to 8034 (30\%). At Minkon Mingon, the highest value regardless to the fertilization was recorded in Ngon kribi (55\%) while the lowest value was observed in Ekobele (33.38\%). All the other varieties had intermediate values for the root colonization frequency in each site, respectively (Table 2). The Tyele site showed closer root colonization status among varieties, although we observed the lowest average value (fertilized and non-fertilized) in 8034. The frequency of root colonization was slightly affected following the application of Fertilizers. However, the frequency of root colonization of all the fertilized plots in the site of Tyele was higher than that of non-fertilized (Table 2). On the other hand, in the site of Minkon Mingon, the frequency of root colonization of all the fertilized plots was lower than that of the not fertilized. In the site of Mekoto, only varieties TMS92/0326 and Ngon kribi had a frequency of root colonization higher at fertilized plots (Table 2).

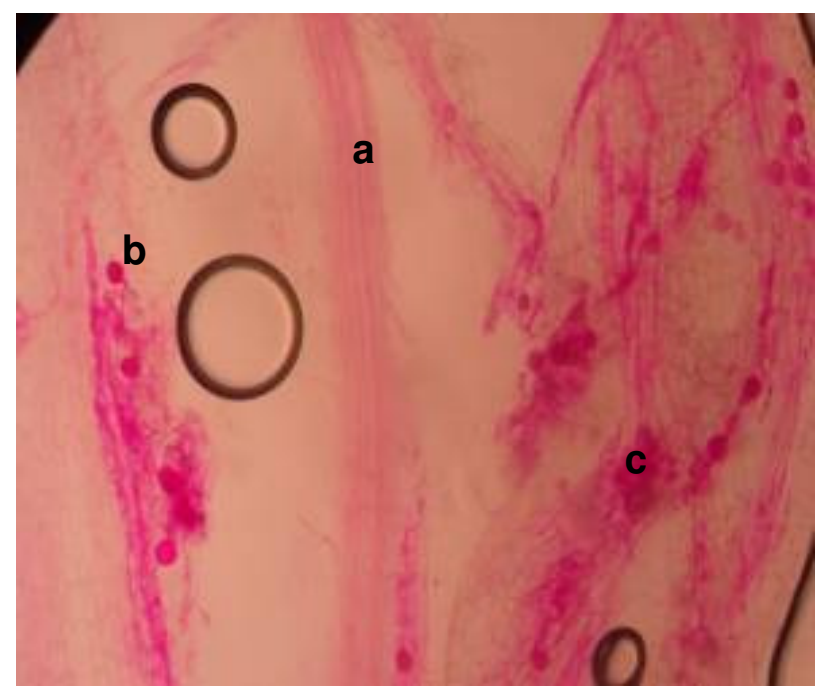

Figure 2: Characteristic structures of AMF in cassava fine roots stained with acid fushin a: hyphae, b: spores, c: vesicles 


Begoude et al. J. Appl. Biosci. $2016 \quad$ Composition of arbuscular mycorrhizal fungi associated with
cassava (Manihot esculenta Crantz) cultivars as influenced by chemical fertilization and tillage in Cameroon

Table 2: Frequency (\%) of root colonization by the AM fungi: effect of cassava varieties and fertilization within each site.

\begin{tabular}{l|c|c|c|c}
\hline Varieties & Fertilization & Mekoto & Minkon Mingon & Tyele \\
\hline $92 / 0326$ & Fertilized & $63.33 \mathrm{c}$ & $30.00 \mathrm{ab}$ & $60.00 \mathrm{~d}$ \\
$92 / 0326$ & Non-Fertilized & $26.33 \mathrm{a}$ & $53.33 \mathrm{~d}$ & $36.67 \mathrm{ac}$ \\
$96 / 1414$ & Fertilized & $33.33 \mathrm{ab}$ & $33.33 \mathrm{ac}$ & $53.33 \mathrm{c}$ \\
$96 / 1414$ & Non-Fertilized & $63.33 \mathrm{c}$ & $63.33 \mathrm{~d}$ & $43.33 \mathrm{ad}$ \\
8034 & Fertilized & $23.33 \mathrm{a}$ & $43.33 \mathrm{bc}$ & $46.67 \mathrm{bcd}$ \\
8034 & Non-Fertlized & $36.67 \mathrm{ab}$ & $56.67 \mathrm{~d}$ & $26.67 \mathrm{a}$ \\
Ngon Kribi & Fertilized & $60.00 \mathrm{c}$ & $43.33 \mathrm{bc}$ & $46.67 \mathrm{bcd}$ \\
Ngon Kribi & Non-Fertlized & $46.67 \mathrm{bc}$ & $66.67 \mathrm{~d}$ & $33.33 \mathrm{ab}$ \\
Ekobele & Fertilized & $46.67 \mathrm{bc}$ & $23.43 \mathrm{a}$ & $56.67 \mathrm{~d}$ \\
Ekobele & Non-Fertlized & $60.00 \mathrm{c}$ & $43.33 \mathrm{bc}$ & $46.67 \mathrm{bcd}$ \\
\hline Sign. Trait $\left(\mathrm{P}_{0.05}\right)$ & & $* * *$ & $* *$ & $*$ \\
\hline
\end{tabular}

In a column, values with same letters are not significantly different at the indicated level of significance. ${ }^{* * \star}$ Significant at $P \leq 0.001$, ${ }^{* *}$ significant at $P \leq 0.01$, ${ }^{*}$ significant at $P \leq 0.05$. In each site, one-way ANOVA was applied in treatments (variety+fertilization system) using CropStat ver.7.2

Spores density and distribution: The spore data for the soils collected in the study area were treated separately. As the "site $x$ treatment" interactions were significant, separated analysis was performed using data of each site. In a site, comparisons were made between the varieties and between the fertilized and non-fertilized plots. A similar trend was observed in all the sites and for all the varieties as regards to the effect of fertilization. All the non-fertilized plots generated a higher number of spores than the plots where fertilizers were applied. Furthermore, the total number of spores obtained in the plots planted with the variety Ekobele without fertilization was the highest at Mekoto and
Tyele sites (Table 3). This number was 1.5 to 2.5 times higher than that of the other varieties. A total of three genera of AMF (Glomus, Gigaspora and Acaulospora) were identified after observation of the spores isolated from the collected soils samples (Table 3). From the Mekoto site soil samples, two genera (Glomus and Gigaspora) were identified whereas three genera (Glomus, Gigaspora and Acaulospora) were identified in the soil samples from the sites of Minkon Mingon and Tyele. However, the Glomus kind was most abundant in all the sites. The spore physical characteristics of these three genera are shown in Figure 3.
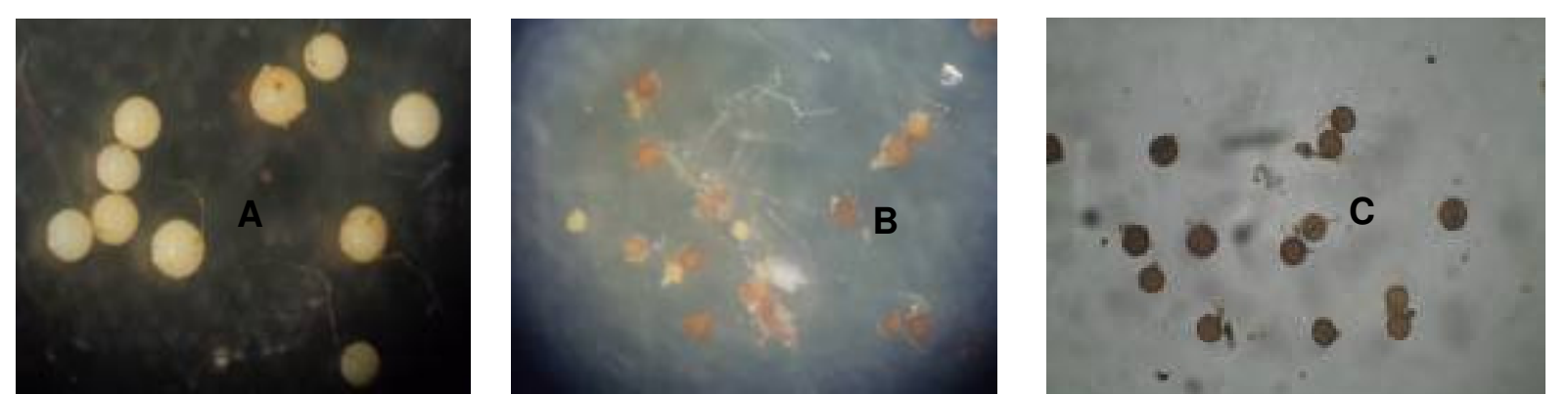

Figure 3: Physical characteristics of Gigaspora (A), Glomus (B) and Acaulospora (C) spores isolated from the soil of the study sites and observed under x100 high-power microscope (www.bio.ukc.ac.uk/beg/protocols/extraction.ht/m) A: Globulous big size spores $(125-250 \mu \mathrm{m})$ without vesicle but with the presence of a suspension bulb and hyph. B: Spores of average to small size $(45-250 \mu \mathrm{m})$ of round shape and divers colour (brown, clear brown, translucent and grey) and without a suspension bulb but with the presence of a hyph. C: Spores of round shape of brown colour measuring 125-250 $\mu \mathrm{m}$ with the presence of a suspension hyph. 


\section{Begoude et al. J. Appl. Biosci. 2016 Composition of arbuscular mycorrhizal fungi associated with}

cassava (Manihot esculenta Crantz) cultivars as influenced by chemical fertilization and tillage in Cameroon

Table 3: Spore density (no. Spore $100 \mathrm{~g}^{-1}$ ) and composition of AMF of rhizosphere samples associated with cassava in Bityili.

\begin{tabular}{|c|c|c|c|c|}
\hline Sites & Varieties & Fertilization & Total spore density & AMF genera (density) \\
\hline \multirow{11}{*}{ Mekoto } & 92/0326 & Fertilized & $167.67 \mathrm{ab}$ & $\mathrm{GI}(167.34), \mathrm{Gi}(0.33)$ \\
\hline & $92 / 0326$ & Non-Fertlized & $341.33 \mathrm{~cd}$ & GI (all) \\
\hline & $96 / 1414$ & Fertilized & $058.33 \mathrm{a}$ & Gl (all) \\
\hline & $96 / 1414$ & Non-Fertlized & $404.00 \mathrm{~d}$ & GI (all) \\
\hline & 8034 & Fertilized & $160.67 \mathrm{ab}$ & Gl (all) \\
\hline & 8034 & Non-Fertlized & $342.67 \mathrm{~cd}$ & Gl (all) \\
\hline & Ngon Kribi & Fertilized & $216.00 \mathrm{bc}$ & Gl (all) \\
\hline & Ngon Kribi & Non-Fertlized & $646.33 \mathrm{e}$ & Gl (all) \\
\hline & Ekobele & Fertilized & $128.00 \mathrm{ab}$ & Gl (all) \\
\hline & Ekobele & Non-Fertlized & $1022.0 \mathrm{f}$ & GI (all) \\
\hline & \multicolumn{2}{|c|}{ Sign. Trait $\left(\mathrm{P}_{0.05}\right)$} & $\star * *$ & \\
\hline \multirow{11}{*}{ Minkon Mingon } & $92 / 0316$ & Fertilized & $167.67 \mathrm{ab}$ & $\mathrm{GI}(\mathrm{all})$ \\
\hline & $92 / 0326$ & Non-Fertlized & $302.22 \mathrm{~cd}$ & GI (301.22), Ac (1) \\
\hline & $96 / 1414$ & Fertilized & $051.00 \mathrm{a}$ & GI (all) \\
\hline & $96 / 1414$ & Non-Fertlized & $541.67 \mathrm{f}$ & GI (541.37), Gi (0.3) \\
\hline & 8034 & Fertilized & $183.67 \mathrm{bc}$ & GI (178.67), Ac (5) \\
\hline & 8034 & Non-Fertlized & $289.00 \mathrm{bdc}$ & GI (all) \\
\hline & Ngon Kribi & Fertilized & $087.67 \mathrm{a}$ & Gl (all) \\
\hline & Ngon Kribi & Non-Fertlized & $169.33 a b$ & GI (168), Ac (1.33) \\
\hline & Ekobele & Fertilized & $333.00 \mathrm{de}$ & $\mathrm{Gl}$ (all) \\
\hline & Ekobele & Non-Fertlized & 449.00 ef & GI (all) \\
\hline & \multicolumn{2}{|c|}{ Sign. Trait $\left(\mathrm{P}_{0.05}\right)$} & $* * *$ & \\
\hline \multirow{11}{*}{ Tyele } & $92 / 0316$ & Fertilized & $144.67 \mathrm{a}$ & GI (all) \\
\hline & $92 / 0326$ & Non-Fertlized & $311.00 \mathrm{~b}$ & GI (all) \\
\hline & $96 / 1414$ & Fertilized & $124.00 \mathrm{a}$ & Gl (all) \\
\hline & $96 / 1414$ & Non-Fertlized & $515.00 \mathrm{c}$ & $\mathrm{Gl}$ (503.67), Ac (11.33) \\
\hline & 8034 & Fertilized & $116.00 \mathrm{a}$ & $\mathrm{Gl}(115.7), \mathrm{Gi}(0.3)$ \\
\hline & 8034 & Non-Fertlized & $564.00 \mathrm{c}$ & GI (562.7), Gi (1.3) \\
\hline & Ngon Kribi & Fertilized & $057.00 \mathrm{a}$ & Gl (all) \\
\hline & Ngon Kribi & Non-Fertlized & $234.00 \mathrm{a}$ & Gl (all) \\
\hline & Ekobele & Fertilized & $126.33 a$ & $\mathrm{Gl}$ (all) \\
\hline & Ekobele & Non-Fertlized & $691.00 \mathrm{c}$ & GI (690.7), Gi (0.3) \\
\hline & \multicolumn{2}{|c|}{ Sign. Trait $\left(\mathrm{P}_{0.05}\right)$} & $* * *$ & \\
\hline
\end{tabular}

In a site, the values of spore density with same letters are not significantly different at the indicated level of significance. ${ }^{* * *}$; significant at $P \leq 0.001$. In each site, one-way ANOVA was applied in treatments (variety + fertilization system) using CropStat ver. 7.2. Gl: Glomus, Gi: Gigaspora, Ac: Acaulospora.

Effect of tillage on AMF abundance and density: Overall, AMF abundance was $35.56 \%$ in Andom, varying between $30.8 \%$ and $38.3 \%$. In each site, the frequency of root colonization was compared for the selected two varieties and tillage. When looking at the effect of tillage on AMF abundance as represented by 
the colonization frequency (Table 4), no significant difference was observed between tilled and non-tilled plots of a variety for site 1 . In site 2, non-tilled TMS96/1414 plots showed significantly higher AMF abundance as compared to tilled plots while the opposite was observed in site 3 for the same variety. In this site 3, the non-tilled TMS-92/0326 plots also had significantly higher AMF abundance as compared to the tilled. Generally, roots from plants collected in non-tilled plots displayed mostly the highest rate of colonization.

Table 4: Frequency (\%) of root colonization by the AM fungi: effect of tillage within each site.

\begin{tabular}{|c|c|c|c|c|}
\hline Varieties & Cropping system & Site 1 & Site 2 & Site 3 \\
\hline $92 / 0326$ & Tillage & $16.67 \mathrm{a}$ & $30.00 \mathrm{ab}$ & $26.67 \mathrm{a}$ \\
\hline $92 / 0326$ & Non-tillage & $20.00 \mathrm{a}$ & $20.00 \mathrm{a}$ & $43.33 \mathrm{bc}$ \\
\hline $96 / 1414$ & Tillage & $56.67 \mathrm{~b}$ & $26.67 \mathrm{a}$ & $46.67 \mathrm{c}$ \\
\hline $96 / 1414$ & Non-tillage & $60.00 \mathrm{~b}$ & $46.67 \mathrm{~b}$ & $33.33 \mathrm{a}$ \\
\hline \multicolumn{2}{|c|}{ Sign. Trait $\left(\mathrm{P}_{0.05}\right)$} & $* *$ & * & * \\
\hline
\end{tabular}

Spores density and distribution: The soil disturbance strongly decrease the total density of spores compared to undisturbed soils (Table 5). At all sites, the highest density of spore was recorded in the soils sampled in non-tilled plots. From this experiment, three genera of
AMF were recorded. The genus Glomus was the most widely distributed. It was found in all the sampling sites. The next most widely distributed genus was Gigaspora, which appeared in site 1 and 3 . The genus Acaulospora was only found at one site (Table 5).

Table 5: Spore density (no. Spore $100 \mathrm{~g}^{-1}$ ) and composition of AMF of rhizosphere samples associated with cassava in Andom

\begin{tabular}{|c|c|c|c|c|}
\hline Sites & Varieties & Cropping system & Total spore density & AMF genera (density) \\
\hline 1 & $\begin{array}{l}92 / 0326 \\
92 / 0326 \\
96 / 1414 \\
96 / 1414 \\
\text { Sign. Trait }\left(\mathrm{P}_{0.05}\right)\end{array}$ & $\begin{array}{l}\text { Tillage } \\
\text { Non-tillage } \\
\text { Tillage } \\
\text { Non-tillage }\end{array}$ & $\begin{array}{l}033.33 \mathrm{a} \\
070.33 \mathrm{a} \\
072.00 \mathrm{a} \\
323.67 \mathrm{~b} \\
* *\end{array}$ & $\begin{array}{l}\text { GI (31.33), Ac (2) } \\
\text { GI (69.67), Ac (0.66) } \\
\text { GI (66.67), Gi (5.33) } \\
\text { GI (all) }\end{array}$ \\
\hline 2 & $\begin{array}{l}92 / 0326 \\
92 / 0326 \\
96 / 1414 \\
96 / 1414 \\
\text { Sign. Trait }\left(P_{0.05}\right)\end{array}$ & $\begin{array}{l}\text { Tillage } \\
\text { Non-tillage } \\
\text { Tillage } \\
\text { Non-tillage }\end{array}$ & $\begin{array}{l}015.67 a \\
319.33 c \\
041.67 a \\
106.67 b \\
* * *\end{array}$ & $\begin{array}{l}\text { GI (all) } \\
\text { GI (all) } \\
\text { GI (all) } \\
\text { GI (all) }\end{array}$ \\
\hline 3 & $\begin{array}{l}92 / 0326 \\
92 / 0326 \\
96 / 1414 \\
96 / 1414 \\
\text { Sign. Trait }\left(\mathrm{P}_{0.05}\right)\end{array}$ & $\begin{array}{l}\text { Tillage } \\
\text { Non-tillage } \\
\text { Tillage } \\
\text { Non-tillage }\end{array}$ & $\begin{array}{l}140.00 \mathrm{a} \\
771.00 \mathrm{~b} \\
041.00 \mathrm{a} \\
371.00 \mathrm{a} \\
*\end{array}$ & $\begin{array}{l}\text { GI (all) } \\
\text { GI (754), Gi (17) } \\
\text { GI (all) } \\
\text { GI (all) }\end{array}$ \\
\hline
\end{tabular}

In a site, the values of total spore density with same letters are not significantly different at the indicated level of significance. ${ }^{* * *}$; significant at $P \leq 0.001$; ${ }^{* *}$; significant at $\mathrm{P} \leq 0.01$; ${ }^{*}$; significant at $\mathrm{P} \leq 0.05$. In each site, one-way ANOVA was applied in treatments (variety + cropping system) using CropStat ver. 7.2. GI: Glomus, Gi: Gigaspora, Ac: Acaulospora. 


\section{DISCUSSION}

Cassava is known to form mycorrhizal symbiosis (Oyetunji \& Osonubi, 2007; Straker et al., 2010; Bi Voko et al., 2013; Ceballos et al., 2013). This study reports the root colonization, the population density and composition of AMF in a selection of cassava cropping systems in Cameroon. The soils of all the studied areas were all acidic with similar chemical composition except that when non-cultivated, the Bityili soil had a higher level of available $P$ and a lower CEC compared to that of Andom. Interestingly, when both soils are analyzed after 10 months cassava growth, the Bityili soil developed significantly higher $\mathrm{N}, \mathrm{S}$ and a lower $\mathrm{C} / \mathrm{N}$, added to the increased available P. AMF were present in all the study sites both in cassava roots and in soil with variable levels of colonization regardless of plant variety and cropping system, suggesting that the plant is strongly mycorrhizal dependent.. This study reported that the mycorrhizal status between the varieties within and between locations was the most heterogenous. In some fields, frequency of root colonization was low, while in other fields high colonization levels were recorded. This suggests that the level of root colonization was probably more dependent on the environmental conditions than on the plant variety. The overall cassava root colonization in Bityili (southern region) was higher than that of Andom (eastern part). Root colonization and plant mycorrhizal dependency may be environment-dependent traits (Smith \& Read, 2008). Another factor, which could have affected root colonization, is the size of some AM fungal species population in soil. Although we did not estimate this parameter in the present study, other reports showed strong operation of the degree of host-fungus specificity (Straker et al., 2010; Bi Voko et al., 2013). On the other hand, the better AMF colonization status of cassava in Bityili (45\%) as compared to that in Andom (35\%) might have enhanced the soil residual nutrients after 10 months cultivation as evidenced by soil data in Table 1 . In this study, the application of fertilizers dramatically alters the interaction between cassava and mycorrhizal community. Though from the root colonization frequency, the fertilization effect was less uniform, it was clear from the spore density recorded in both fertilized and non-fertilized plots that the presence of fertilizers in the soil has a negative impact on the AMF. This result corroborates previous reports where it was indicated that fertilizer could negate the mycorrhizal effect in the field, reducing infection of roots and generation of spores (Rubio et al., 2003; Alguacil et al., 2010). Generally, in a nutrient-rich environment, a plant can directly uptake enough nutrient from the soil, without the catering service provided by the AMF partners. As a result, the dependency of plants on their AMF partners gradually diminishes, and AMF community richness and diversity decline (Alguacil et al., 2010; Borriello et al., 2012; Liu et al., 2012). Owing to their role in the promotion of plant health, soil nutrition improvement and soil aggregate stability, AMF are biotic soil components that, when impoverished, can lead to a less efficient ecosystem functioning. Therefore, the cultivation practices adopted for cassava should include appropriate management of these symbiotic fungi with a view to sustainable agriculture especially as the presence of a high degree of AMF biodiversity indicates good soil quality (Barr et al., 2001).Soil disturbance highly reduced the root colonization as well as the density of spores. Reduction in the spore numbers may decrease the availability of inoculum in the soil and hence have detrimental effects on the subsequent formation of mycorrhiza in young plant roots (Dodd et al., 1990; McGonigle \& Miller, 1993). These results are in accordance with previous reports for other types of tropical soils (Castillo et al., 2006; Cornejo et al., 2009; Curaqueo et al., 2010) which showed that hyphal densities of AMF were greatest in non-tilled than tilled treatments. The lower density of AM fungi spore in tilled plots could be explained by the strong influence of the soil disturbation generated by ploughing (Galvez et al., 2001; Kabir, 2005). In this sense, soil ploughing reduces the ability of AM fungi to colonize roots, breaking down their hyphal network (Alguacil et al., 2008). On the opposite, in soils under non-tilled conditions, the hyphal network remains intact; and consequently the density of active hyphae is usually greater than soil managed under tilled conditions (Kabir, 2005; Cornejo et al., 2009). The present study showed that Glomus was the predominant genus in terms of spore density and morphotypes (Table 3, 5). A similar finding was obtained from rhizosphere soil under cassava in Brazil (De Souza et al., 1999), in South Africa (Straker et al., 2010) and in Cote d'Ivoire (Bi Voko et al., 2013). Glomus species are considered as widespread fungi in many ecosystems (Sýkorová et al., 2007). They dominate habitats tropical regions. They usually occur in neutral and slightly alkaline soil (Mukerji et al., 2002). In Thailand, Glomus was the most prevalent AMF genus under Macaranga denticulata (Youpensuk et al., 2004), an indigenous colonizing tree of North Thailand (Nandakwang et al., 2008). The cycle of genus Glomus 


\section{Begoude et al. J. Appl. Biosci. 2016 Composition of arbuscular mycorrhizal fungi associated with cassava (Manihot esculenta Crantz) cultivars as influenced by chemical fertilization and tillage in Cameroon}

seems not to be affected by nutrient rich environment and tillage since it was found in all fields at a high frequency. Other genera were less common in the present study, with only a few morphotypes, such as Acaulospora and Gigaspora. Members of Acaulospora have been identified mainly in low input farming systems, forest and grassland soils. They are considered as facultative symbionts adapted to a wide array of soil and host species, appearing in soils of widely different $\mathrm{pH}$ and nutrient availability (Sieverding, 1991; Shepherd et al., 1996; Straker et al., 2010). Moreover, Acaulospora species are frequently associated with acidic soil (Abbott \& Robson, 1991). Acaulospora species have been demonstrated to be very effective in $\mathrm{P}$ uptake, and in the transfer to the host plant, compared to Glomeraceae species (Jacobsen et al., 1992). In line with these findings, Acaulosporaceae species have been considered to decrease largely under high input $P$ fertilization (Lin et

\section{ACKNOWLEDGMENTS}

This work was supported by the Science and Technology Research Partnership for Sustainable Development (SATREPS) program of the Japan Science and Technology Agency (JST) and the Japan International Cooperation Agency (JICA), the Ministry

\section{REFERENCES}

Abbott LK and Robson AD, 1991. Factors influencing the occurrence of vesicular arbuscular mycorrhizas. Agriculture Ecosystems and Environment 35: 121-150.

Adriano-Anaya ML, Solis-Domínguez F, Gavito-Pardo ME, Salvador-Figueroa M, 2006. Agronomical and environmental factors influence root colonization, sporulation and diversity of arbuscular mycorrhizal fungi at a specific fenological stage of banana trees. Journal of Agronomy 5: 11-15.

Alguacil MM, Lumini E, Roldan A, Salinas-Garcia JR, Bonfante P, Bianciotto V, 2008. The impact of tillage practices on arbuscular mycorrhizal fungal diversity in subtropical crops. Ecological Applications 18: 527-536.

Alguacil MM, Lozano Z, Campoy MJ, Roldán A, 2010. Phosphorus fertilisation management modifies the biodiversity of AM fungi in a tropical savannah forage system. Soil Biology and Biochemistry 42: 1114-22.

Araki S. and Saito H, 2013. Monitoring soil erosion and water run-off by different soil conservation al., 2012). Gigaspora species often, predominate in sandy soils such as dunes (Lee \& Koske, 1994). Many agricultural soils in southern Cameroon have a low sand content. Gigaspora produces large spores and these require a longer period to develop than the smallspored species (Hepper, 1984). Members of this group are more adaptive to changing environmental conditions (Stutz \& Morton, 1996). Species of Gigaspora are much more frequently associated with wild plants than with field crops (Gai et al., 2006) and they are able to cope well with nutrient rich environments (Lin et al., 2012; Liu et al., 2012). Cassava was well colonized by AMF in all field locations studied. The ability of this crop to harbour AMF across a wide range of site conditions makes it a good potential crop for large-scale plantations. Despite the high mycotrophic potential of cassava, results from this study provided evidence that management practices can strongly affect its mycorrhizal status.

of Scientific Research and Inovation (MINRESI) of Cameroon, which co-funded the Cameroon Forestsavannah sustainability (FOSAS) project. To SATREPS, we express our sincere gratitude.

methods: results from Andom experiments between 2010 and 2012. In: Woin N, Foahom B, and Araki S eds. Progress Report 2012, Forest Savanna sustainability Project, Cameroon. FOSAS Project, IRAD, Cameroon (Yaoundé) pp. 86-89.

Araki S. and Sarr PS, 2013. The effect of cassava cultivation on soil acidification. In: Hanna R, Araki $S$ eds. A report on Cassava Science Day: Cassava performance under different soil management. FOSAS Activity Series No1, FOSAS, IRAD, Cameroon (Yaoundé) pp. 3236.

Barr J, 2011. The value of mycorrhizal fungi for sustainable and durable soils. In: Silva AP and Sol M eds. Fungi: types, environmental impact and role in disease. Nova Science Publishers Inc. Hauppauge, New York, 531 pp.

Bi voko DR, Nandjui J, Sery JMD, Fotso B, Amoa JA, Kouadio MSA, Coulibaly S, Niamke S, Zeze A, 2013. Abundance and diversity of Arbuscular mycorrhizal fungal (AMF) communities associated with cassava (Manihot esculenta 


\section{Begoude et al. J. Appl. Biosci. 2016 Composition of arbuscular mycorrhizal fungi associated with cassava (Manihot esculenta Crantz) cultivars as influenced by chemical fertilization and tillage in Cameroon}

Crantz) rhizosphere in Abengourou, East Côte d'Ivoire. Journal of Ecology and Natural Environment 5(11): 360-370.

Borriello R, Lumini E, Girlanda M, Bonfante P, Bianciotto V, 2012. Effects of different management practices on arbuscular mycorrhizal fungal diversity in maize fields by a molecular approach. Biology and Fertility of Soils 48: 911-22.

Castillo C, Rubio R, Rouanet JL, Borie F, 2006. Early effects of tillage and crop rotation on arbuscular mycorrhizal fungal propagules in an Ultisol. Biology and Fertility of Soils 43: 83-92.

Ceballos I, Ruiz M, Fernandez C, Pena R, Rodriguez A, Sanders IR, 2013. The in vitro mass-produced model mycorrhizal fungus, rhizophagus irregularis, significantly increases yields of the globally important food security crop cassava. PLOS ONE 8(8): e70633.

Cornejo P, Rubio R, Borie F, 2009. Mycorrhizal propagule persistence in a succession of cereals in a disturbed and undisturbed andisol fertilized with two nitrogen sources. Chilean Journal of Agricultural Research 69: 426-434.

Curaqueo G, Acevedo E, Cornejo P, Seguel A, Rubio $R$, Borie $F, 2010$. Tillage effect on soil organic matter, mycorrhizal hyphae and aggregates in a Mediterranean agroecosystem. Journal of Soil Science Plant Nutrition $10: 12-21$.

De Souza FA, Trufem SFB, De Almeida DL, Da Silva EMR, Guerra JMG, 1999. Effect of pre-crops on the inoculum potential of arbuscular mycorrhizal fungi and cassava yield. Pesquisa Agropecuaria Brasileira 34: 1913-1923.

Declerck S, Plenchette C, Strullu DG, 1995. Mycorrhizal dependency of banana (Musa acuminata, AAA group) cultivar. Plant and Soil 176: 183-187.

Dodd JC, Arias I, Koomen I, Hayman DS, 1990. The management of populations of vesiculararbuscular mycorrhizal fungi in acid-infertile soils of a savannah ecosystem. I. The effect of precropping and inoculation with VAM-fungi on plant growth and nutrition in the field. Plant and Soil 122: 229-240.

Douds DD Jr. and Millner PD, 1999. Biodiversity of arbuscular mycorrhizal fungi in agroecosystems. Agriculture Ecosystems and Environment $74:$ 77-93.

Emmanuel T, 2013. Amélioration de la commercialisation et de transformation du manioc au Cameroun: contraintes et perspectives de la chaîne de valeur, Dans: Reconstruire le potentiel alimentaire de l'Afrique de l'Ouest. Elbehri A, Edition, FAO/FIDA. (in French)

Fedderman N, Finlay R, Boller T, Esfstrand M, 2010. Functional diversity in arbuscular mycorrhiza: the role of gene expression, phosphorus nutrition and symbiotic efficiency. Fungal Ecology 3: 1-8.

Franke-Snyder M, Douds DD, Galvez L, Phillips JG, Wagoner P, Drinkwater L, Morton JB, 2001. Diversity of communities of arbuscular mycorrhizal (AM) fungi present in conventional versus low-input agricultural sites in eastern Pennsylvania, USA. Applied Soil Ecology 16: 35-48

Gai JP, Christie P, Feng G, Li XL, 2006. Twenty years of research on community composition and species distribution of arbuscular mycorrhizal fungi in China: a review. Mycorrhiza 16: 229239.

Galvez L, Douds DD, Drinkwater LE, Wagoner P, 2001. Effect of tillage and farming system upon VAM fungus populations and mycorrhizas and nutrient uptake of maize. Plant and Soil 228: 299-308.

Hepper CM, 1984. Regulation of spore germination of the vesicular arbuscular mycorrhizal fungus Acaulospora laevis by soil pH. Transactions of the British Mycological Society 83: 154-156.

Jakobsen I, Abbott LK, Robson AD, 1992. External hyphae of vesicular-arbuscular mycorrhizal fungi associated with Trifolium subterraneum L. 1. Spread of hyphae and phosphorus inflow into roots. New Phytology 120: 371-380.

Kabir Z, 2005. Tillage or no-tillage: impact on mycorrhizae. Canadian Journal of Plant Science 85: 23-29.

Kim K, Yim W, Trivedi P, Madhaiyan M, Boruah HPD, Islam MR, 2009. Synergistic effects of inoculating arbuscular mycorrhizal fungi and Methylbacterium oryzae strains on growth and nutrient uptake of red pepper (Capsicum annuum L.). Pland and Soil 327:429-440.

Lee PJ. and Koske RE, 1994. Gigaspora gigantia: Seasonal, abundance and ageing of spores in a sand dune. Mycological Research 98: 45457.

Li H, Ye ZH, Chan WF, Chen XW, Wu FY, Wu SC, Wong MH, 2011. Can arbuscular mycorrhizal 


\section{Begoude et al. J. Appl. Biosci. 2016 Composition of arbuscular mycorrhizal fungi associated with cassava (Manihot esculenta Crantz) cultivars as influenced by chemical fertilization and tillage in Cameroon}

fungi improve grain yield, as uptake and tolerance of rice grown under aerobic conditions? Environmental Pollution 159: 2537-2545.

Lin X, Feng Y, Zhang H, Chen R, Wang J, Zhang J, 2012. Long-term balanced fertilization decreases arbuscular mycorrhizal fungal diversity in an arable soil in north China revealed by 454 pyrosequencing. Environtal Science and Technology 46: 5764-71.

Lingua G, Agostino GD, Massa N, Antosiano M, Berta G, 2002. Mycorrhiza-induced differential response to a yellow disease in tomato. Mycorrhiza 12: 191-198.

Liu Y, Shi G, Mao L, Cheng G, Jiang S, Ma X, 2012. Direct and indirect influences of $8 \mathrm{yr}$ of nitrogen and phosphorus fertilization on Glomeromycota in an alpine meadow ecosystem. New Phytology 194: 523-35.

McGonigle TP. and Miller MH, 1993. Responses of mycorrhizae and shoot phosphorus of maize to the frequency and timing of soil disturbance. Mycorrhiza 4: 63-68.

Miransari M, Bahrami HA, Rejali F, Malakouti MJ, 2009. Effects of arbuscular mycorrhiza, soil sterilization, and soil compaction on wheat (Triticum aestivum L.) nutrients uptake. Soil and Tillage Research 104: 48-55.

Mukerji KG, Manoharachary C, Chamola BP, 2002. Techniques in mycorrhizal studies. Kluwer Academic Publishers, Dordrecht, Boston, London.

Nandakwang P, Elliott S, Dell B, Teaumroong N, Lumyong S, 2008. Arbuscular mycorrhizal status of indigenous tree species used to restore seasonally dry tropical forest in Northern Thailand. Research Journal of Microbiology 3: 51-61.

Oyetunji OJ. and Osonubi O, 2007. Assessment of influence of alley cropping system and Arbuscular Mycorrhizal (AM) Fungi on cassava productivity in derived savannah zone of Nigeria. World Journal of Agricultural Science 3(4): 489-495.

Rubio R, Borie F, Schalchli C, Castillo C, Azcón R, 2003. Occurrence and effect of arbuscular mycorrhizal propagules in wheat as affected by the source and amount of phosphorus fertilizer and fungal inoculation. Applied Soil Ecology 23: 245-255.
Shepherd KD, Jefwa J, Wilson J, Ndufa JK, Ingleby K, Mbuthu KW, 1996. Infection potential of farm soils as mycorrhizal inocula for Leucaena leucocephala. Biology and Fertility of Soils 22: 16-21.

Sieverding E, 1989. Ecology of VAM fungi in tropical ecosystems. Agriculture Ecosystems and Environment 29: 369-390.

Sieverding E, 1991. Vesicular-arbuscular mycorrhiza Management. In: Tropical Agrosystems. GTZ $n^{\circ} 224$ FRG. 281p.

Smith EE, Facelli E, Pope S, Smith FA, 2010. Plant performance in stressful environments. Interpreting new and established knowledge of the roles of arbuscular mycorrhizas. Plant and Soil 326: 3-20.

Smith SE. and Read DJ, 2008. Mycorrhizal Symbiosis. $3^{\text {rd }}$ Edition, Academic Press, Lon-don, UK.

Straker CJ, Hilditch AJ, Rey MEC, 2010. Arbuscular mycorrhizal fungi associated with cassava (Manihot esculenta Crantz). South African Journal of Botany 76: 102-111.

Stutz JC. and Morton JB, 1996. Successive pot cultures reveal high species richness of arbuscular endomycorrhizal fungi in arid ecosystems. Canadian Journal of Botany 74: 1883-1889.

Sýkorová Z, Ineichen K, Wiemken A, Redecker D, 2007. The cultivation bias: different communities of arbuscular mycorrhizal fungi detected in root from the field, from bait plants transplanted to the field, and from a greenhouse trap experiment. Mycorrhiza 18: 114.

Tolly E, 2013. Amélioration de la commercialisation et de transformation du manioc au Cameroun: contraintes et perspectives de la chaîne de valeur, Dans: Reconstruire le potentiel alimentaire de l'Afrique de l'Ouest. Elbehri $\mathrm{A}$, Edition, FAO/FIDA. (in French)

Veresoglou SD, Shaw LJ, Sen R, 2010. Glomus intraradices and Gigospora margarita arbuscular mycorrhizal associations differentially affect nitrogen and potassium nutrition of Plantago lanceolata in a low fertility dune soil. Plant and Soil 340: 481-490.

Vestberg M, Kukkonen S, Saari K, Tuovinen T, Palojärvi A, Pitkänen T, Hurme T, Vepsäläinen M, Niemi M, 2009. Effects of cropping history and peat amendments on the quality of a silt soil cropped with strawberry. Applied Soil Ecology 42: 37-47. 
Yano-Melo AM, Junior OJS, Lima-Filho JM, Melo FN, Maia LC, 1999. Effect of arbuscular mycorrhizal fungi on acclimatization of micropropagated banana plantlets. Mycorrhiza 9: 119-123.

Youpensuk S, Lumyong S, Dell B, Rerkasem B, 2004. Arbuscular mycorrhizal fungi in the rhizosphere of Macaranga denticulata Muell. Arg. and their effect on the host plant. Agroforestry Systems 60: 239-246. 